\title{
Stability of spray-dried chitosan salts derived from lobster chitin as a raw material
}

\author{
Estabilidad de las sales de quitosana, obtenidas por secado de aspersión, derivadas \\ de quitina de langosta \\ De la Paz Nilia'; García Caridad'; Fernández Mirna²; García Lisandra'; Martínez Vivian³ López Orestes"; \\ Nogueira Antonio ${ }^{3}$ \\ 1. Máster en Ciencias Farmacéuticas. Centro de Investigación y Desarrollo de Medicamentos (CIDEM) \\ 2. DraC. Ciencias Farmacéuticas. Profesora Titular, IFAL \\ 3. Técnico, CIDEM \\ 4. DrC. Ciencias Técnicas. Profesor Asistente. Universidad Técnica de Ambato (Ecuador). Facultad de Ciencia de los Alimentos
}

\section{Artículo original Original Article}

\author{
Correspondencia \\ Correspondence \\ Dra C. Mirna Fernández Cervera \\ Dpto. Tecnología y Control de los \\ Medicamentos \\ Instituto de Farmacia y Alimentos (IFAL). \\ Universidad de la Habana. \\ Calle 23 No. 21425 e/ 214 y 222, \\ La Habana. Cuba. \\ Teléfonos: 271-4075, 271-9534 \\ mirnafc@ifal.uh.cu

\section{Financiación} \\ Fundings \\ No funding agency for the research \\ work. \\ Conflicto de interés \\ Competing interest \\ Authors declare no conflict of interest.
}

Received: 15.09 .2015 Accepted: 12.10 .2015

\section{RESUMEN}

Objetivos. Desarrollar y validar un método para la determinación del grado de desacetilación molar del acetato de quitosana y lactato de quitosana, y realizar el estudio de estabilidad de ambas sales.

Material y Métodos. Un método espectrofotométrico fue validado según lo establecido internacionalmente para técnicas cuantitativas. Tres lotes industriales de acetato de quitosana y lactato de quitosana, obtenidos mediante secado por aspersión, fueron almacenados bajo condiciones de vida de estante durante doce meses. Se determinaron las características organolépticas, grado de desacetilación molar, pH, pérdida por desecación y el conteo microbiológico al inicio y final del estudio.

Resultados y Discusión. El análisis estadístico demostró que ambos métodos cumplieron con los parámetros internacionales establecidos. Se demostró que los procedimientos desarrollados fueron lineales, específicos, precisos y exactos, por lo que pueden ser empleados en el control de calidad y estudio de estabilidad. Las sales se mantuvieron en forma de polvo de coloración amarillo claro u oscura. Los valores de pérdidas por desecación (2,5 - 5,2 \%), para el acetato y lactato de quitosana, demuestran la calidad de las partículas de quitosana obtenidas por secado por aspersión. Un comportamiento similar fue obtenido para el $\mathrm{pH}$. Las dos sales mantuvieron los parámetros que determinan su calidad, transcurridos los doce meses a temperatura ambiente. Conclusión: El acetato y el lactato de quitosana, almacenados a temperatura ambiente y en lugares secos, en bolsas dobles de polietileno y sacos de papel multicapas, conservan durante doce meses sus características físicas, químicas y microbiológicas.

Palabras claves: espectrofotometría, acetato de quitosana, lactato de quitosana, estudios de validación, estabilidad.

\section{ABSTRACT}

Aim. The objective of this work was to develop and validate a method for determining the degree of molar deacetylation of chitosan acetate and chitosan lactate, as well as to study the stability of both salts.

Materials and Methods. A spectrophotometric method was validated according to internationally-established quantitative techniques. Three industrial batches of chitosan acetate and chitosan lactate, obtained by spray drying, were stored under shelf life conditions for twelve months. Organoleptic characteristics, the degree of molar deacetylation, $\mathrm{pH}$, loss on drying and microbiological count were determined at the beginning and end of the study.

Results and Discussion. The statistical data proved that the two methods complied with international standards for the validation of analytical techniques. It was shown that the procedures developed were linear, specific, precise and accurate, so they can be used for the purposes of quality control and stability study of the polymer salts. Salts remained in powder form, with a light-yellow to dark-yellow coloration. Values of loss on drying (2.5 - 5.2\%) of chitosan salt using acetic or lactic acid, as a solvent, indicated the good quality of spray-dried particles of chitosan. Similar behavior was obtained regarding $\mathrm{pH}$. The two salts stayed within the parameters that determine their quality, both in the initial stage and after twelve 
months at room temperature. Conclusion: Spray drying chitosan acetate and chitosan lactate, stored at room temperature in a dry place, in double polyethylene bags and multilayer paper bags, kept their physical, chemical and microbiological characteristics for a period of twelve months.

Keywords: spectrophotometry, chitosan acetate, chitosan lactate, Validation studies, stability.

\section{INTRODUCTION}

Chitosan is a derivative of chitin, the second most abundant polymer in nature, which is a supporting material of crustaceans, insects, and fungal mycelia. Among the different species of crustaceans, shrimp and crab shells have been widely used for the isolation of chitin ${ }^{1}$. Although the polymer was discovered in 1859, its physicochemical and micromeritic properties have not been fully elucidated to date. The incomplete characterization of chitosans and their commercial variability have discouraged the pharmaceutical industry from adopting it as a pharmaceutical excipient or formulation component ${ }^{2}$.

Chitosan is of major importance for industrial purposes because it possesses excellent properties such as biocompatibility, biodegradability, non-toxicity and absorption properties $^{3-5}$. The potential of chitosan as a novel excipient which might yet receive extensive application in pharmaceutical products has been highlighted in several reports ${ }^{6-12}$.

Chitosan is water-insoluble, but soluble in weak organic acid solutions. Chitosan derivatives in the form of acetate, ascorbate, lactate, and malate are water-soluble; therefore chitosan salification may significantly modify its solubility characteristics. Different chitosan salts display different physical-chemical properties depending on the nature of the counter ion. It has been approved by pharmaceutical authorities, and a monograph relating to chitosan hydrochloride was included in the fourth edition of the European Pharmacopeia ${ }^{13}$.

The spray-drying technique has been applied to chitosan suspensions, chitosan salts, and different chitosan matrixes ${ }^{9,14-18}$.

Our previous studies involved the optimization of the alkaline N-deacetylation process to obtain chitosan from lobster chitin (Panulirus argus). In addition, physical-chemical and microbiological characteristics of chitosan were in good agreement with the limits of chitosan-like pharmaceutical excipients ${ }^{19,20}$. To evaluate the stability of chitosan as a raw material, a potentiometric method was developed and validated for determining the degree of deacetylation of biopolymer ${ }^{21}$. Previously, we demonstrated that chitosan derived from lobster chitin can be successfully salified with acetic, lactic and citric acids by means of spray drying ${ }^{22}$.

Several methods for determining the degree of deacetylation (DD) have been employed, from simple, such as $\mathrm{pH}$ metric titration and potentiometric ${ }^{23-25}$, UV-Vis spectros$\operatorname{copy}^{26}$, infrared spectroscopy ${ }^{27}$, to complex ones, which require complicated and expensive equipment, such as ${ }^{1} \mathrm{H}$ NMR and ${ }^{13} \mathrm{C}$ NMR spectroscopy ${ }^{27,28-31}$. Methods for determining the degree of deacetylation by titration are cheap and based on readily accessible reagents and equipment, while a disadvantage is the relatively long time required for sample preparation and for the titration itself. NMR methods usually involve many analytical procedures for performing measurements and calculations and many ways of interpreting results. Moreover, although NMR spectroscopy is probably the most precise method, it is not suitable for routine DD measurements due to the high costs (deuterated solvents, depreciation of equipment, specialized staff) and the time-consuming sample preparation procedure involved. Most laboratories must rely on less advanced, simpler and cheaper techniques. Therefore, it is important to select a technique that is reliable, precise, accurate, reproducible and inexpensive.

Even though chitosan as a raw material is obtainable from a great variety of sources, no method that could be used as reference has been described in pharmacopoeias. Consequently, reliable validated methods are required to determine the DD of chitosan.

The validation of an analytical method is necessary in laboratory studies to guarantee the fulfillment of a number of essential requirements for the future analytical application of the method. It serves to provide greater degrees of reliability and confidence in productive processes or in analytical methods and in the veracity of the results obtained. These requirements are expressed in terms of analytical parameters $^{32,33}$.

The objective of this study was to develop a precise, selective, exact and linear spectrophotometric method to determine the degree of molar deacetylation of chitosan salts as a raw material, as well as to evaluate the stability of spraydried chitosan salts for a period of 12 months.

\section{MATERIALS AND METHODS}

\section{Chemical products and reagents}

Spray-dried chitosan salts (acetate and lactate), were produced in an industrial spray-drying plant in a Cuban establishment in accordance with the previously-reported pro- 
cedure $^{27}$. Lactic acid (BDH, England), acetic acid (Merck, Germany), N-acetylglucosamine (Scharlau, Spain) and all other reagents employed were of analytical grade.

\section{UV-VIS Spectroscopy method}

The UV method was performed on a UV-1601 UV-VIS spectrophotometer (Shimadzu Corporation, Japan). The test solution was prepared by using exact weights; $0.250 \mathrm{~g}$ of the substance were dissolved in distilled water and diluted to $50.0 \mathrm{~mL}$ with the same solvent, stirring vigorously. $1.0 \mathrm{~mL}$ of this solution was diluted to $100.0 \mathrm{~mL}$ with distilled water. Absorbance was measured from 200 to $205 \mathrm{~nm}$ as the first derivative of the absorbance curve. The $\mathrm{pH}$ of the solution was determined.

Standard solutions were prepared in distilled water at concentrations of $1.0 ; 5.0 ; 15.0$ and $35.0 \mu \mathrm{g} / \mathrm{mL}$ of N-acetylglucosamine. The absorbance from $200 \mathrm{~nm}$ to $205 \mathrm{~nm}$ for each solution as the first derivative of the absorption curve was measured. A calibration curve was established, representing the first derivative at $202 \mathrm{~nm}$ as a function of the Nacetylglucosamine concentration, and the curve slope was calculated by least squares linear regression. The calibration curve was used to determine the equivalent amount of $\mathrm{N}$-acetylglucosamine for the substance to be examined.

The degree of (molar) deacetylation was calculated by using the expression:

$$
\mathrm{GD}(\%)=\frac{100 \cdot M_{1} \cdot\left(C_{1}+C_{2}\right)}{\left(M_{1} \cdot C_{1}\right) \cdot\left[\left(M_{1}+M_{3}\right) \cdot C_{2}\right]}
$$

Where:

$\mathrm{C}_{1}$ : Concentration of chitosan acetate or chitosan lactate $(\mu \mathrm{g} / \mathrm{mL})$ in the test solution

$\mathrm{C}_{2}$ : Concentration of $\mathrm{N}$-acetylglucosamine $(\mu \mathrm{g} / \mathrm{mL})$ in the test solution, determined from the calibration curve using the reference solution

$\mathrm{M}_{1}$ : 203 (relative molecular mass of the N-acetylglucosamine unit in the polymer)

$\mathrm{M}_{3}$ : relative molecular mass of chitosan acetate or lactate. This is calculated from the $\mathrm{pH}$ in the solution, with a $\mathrm{pKa}$ value of 6.8; using the following expressions:

$$
\mathrm{M}_{3}=f \cdot M_{2}+\left[(1+f) \cdot\left(M_{2}+36.5\right)\right]
$$

Where:

$$
\mathrm{f}=\frac{p}{1+p}
$$

$$
\mathrm{p}=10 \cdot(p H-p K a)
$$

$\mathrm{M}_{2}: 161$ (relative molecular mass of the (glucosamine) deacetylated unit in the polymer)

\section{Validation of the spectrophotometric method}

The spectrophotometric method was validated according to parameters established ${ }^{32}$. A similar procedure was carried out in order to analyze chitosan salts, acetate and lactate, respectively.

\section{Selectivity}

Standard, placebo (10\% acetic acid or $10 \%$ lactic acid) and sample solutions were prepared separately as described above. Wavelength scanning was made at 300 - 700 nm. For each case, the absorption spectra were recorded and compared with the spectra obtained from the $100 \% \mathrm{~N}$-acetylglucosamine. The spectrum of the sample must match the chemical's reference substance. Signals should not be observed in the placebo.

\section{Linearity of the system}

Five chitosan salts concentrations in triplicate were analyzed within a range of $50 \%$ to $150 \%$ of the stated theoretical quantity. A calibration curve of experimental concentration expressed as absorbance vs theoretical concentration of $\mathrm{N}$-acetylglucosamine $(\mu \mathrm{g} / \mathrm{mL})$ was plotted. The results were statistically processed using the statistical package for Windows, version 6.01 (multiple linear regression option) and the following parameters were determined: $r$ (coefficient of linear correlation), $\mathrm{r}^{2}$ (coefficient of determination), a (intercept) and b (slope), for a reliability of $95 \%$.

\section{Exactness}

A recovery curve $(\mathrm{Y})$ was plotted of the recovered percentage vs the percentage added $(X)$ of the points equivalent to 80,100 and $120 \%$, analyzed in triplicate at each level of concentration. The results were processed statistically in the same way as those for the calibration curve of system linearity, calculating the percentage of recovery (R) and the coefficient of total variation (CV). Cochran's $G$ test was used to determining whether the concentration factor had any influence on the results. Finally, the student $t$ test was used to demonstrate that there were no significant differences between the average recovery values obtained and the $100 \%$ reference sample. 


\section{Precision}

\section{Repeatability}

For repeatability analysis, samples were evaluated six times, with a concentration equivalent to $100 \%$, within the linearity range of the method. The CV was calculated and compared with established criteria. Determinations were performed by the same analyst, under the same working conditions.

\section{Intermediate precision}

At the same laboratory, two researchers carried out analyses over two days. Triplicate analyses were performed in each case for samples that were equivalent to $100 \%$. Total $\mathrm{CV}$ was calculated. For identical analytical methods, Snedecor's F test was used to check for significant differences between the results obtained by each analyst and the results for each day of analysis by the same analyst. The student $t$ test was used to check for homogeneity for the values obtained between each analyst and between each day of analysis, with a significance level of $\alpha=0.05$.

\section{Stability study}

Three industrial batches of spray-dried chitosan salts, acetate and lactate, were exposed at $30 \pm 2{ }^{\circ} \mathrm{C}$, relative humidity $(\mathrm{RH})=70 \pm 5 \%$ for 12 months (shelf life). Organoleptic characteristics, $\mathrm{pH}$, loss on drying and degree of (molar) deacetylation were determined ${ }^{34,35}$, at the initial stage, as well as after 3, 6, 9 and 12 months. Besides, microbiologic analyses at the beginning and end of the study were carried out $^{32}$.

\section{RESULTS}

UV detection was carried out at $205 \mathrm{~nm}$, with results shown in Table 1, which features UV absorbance values of standard and placebo solutions. The direct UV method allows a rapid quantification of chitosan acetate or lactate without time-consuming sample pre-treatment steps. UV absorbance values show that the $\mathrm{N}$-acetylglucosamine has a maximum at $205 \mathrm{~nm}$, which is mainly due to N-acetylglucosamine. Placebo absorbance value is below $1 \%$ in relation to the sample.

Table 1. Selectivity of spectrophotometric methods

\begin{tabular}{|l|l|l|l|}
\hline & \multicolumn{3}{|c|}{ Absorption values } \\
\hline Placebo & 0.002 & 0.004 & 0.002 \\
\hline Chitosan acetate & 0.708 & 0.703 & 0.689 \\
\hline Chitosan lactate & 0.498 & 0.501 & 0.503 \\
\hline
\end{tabular}

Experimental results in terms of system linearity are shown in Figure 1. Results in terms of statistical processing are summarized in Tables 2 and 3, respectively. The statistical data proved that the two methods complied with international standards for the validation of analytical techniques.

Figure 1. Calibration curve obtained for the linearity of the system

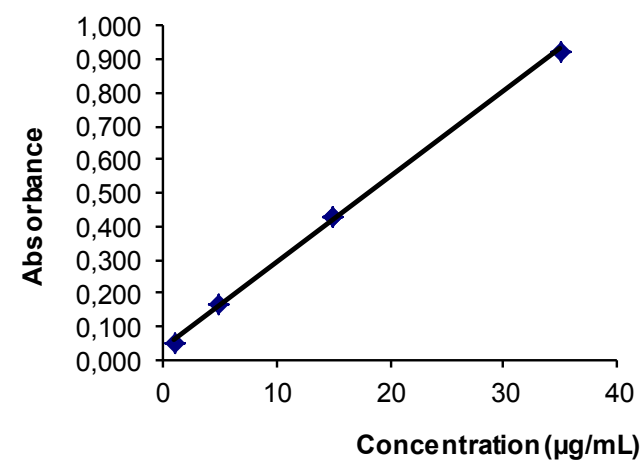

With regard to the stability of both chitosan salts, results are found in Tables 4 and 5, respectively. The stability results indicate that spray-dried chitosan salts appear to be similar in terms of their physical, chemical and microbiological properties.

\section{DISCUSSION}

The advantages of the UV-VIS spectroscopy method are: generally available equipment (UV-Vis spectrometer) and easy measurements. Disadvantages include: the use of expensive chemicals, laborious and time-consuming procedure (calibration curve, etc.), complex procedures of calculation and the fact that the presence of contaminants (absorbing below $210 \mathrm{~nm}$ ) can influence spectra and, hence, the final results.

The first derivative UV method for determining the degree of acetylation was proposed by Muzzarelli and Rocchetti ${ }^{26}$. The principle behind this method was based on the intensity of absorbance of the $\mathrm{N}$-acetyl group in chitin or chitosan. The absorbance of $\mathrm{N}$-acetylglucosamine (at maximum wavelength) was linearly dependent on its concentration in the $1.0-35.0 \mu \mathrm{g} / \mathrm{mL}$ range.

Evidence of system linearity can be confirmed through the established statistical parameters. Within the range studied, the results obtained confirmed the linearity of the methods, given that there was a high correlation between the response obtained and the concentration of the sample, 
and that the statistical criteria from regression analysis had been met.

To evaluate exactness, the recovery percentages (R) of equivalent points at three concentration levels were determined, from which recovery curves were plotted by statistical processing, which confirmed that all established criteria were met in accordance with the linear regression applied. The average recovery coefficients did not exceed the limit of $98 \%$ to $102 \%$. Furthermore, total coefficient of variation was found to be well below $2 \%$, indicating good exactness.

In addition, the influence of the sample concentration on the variance of results $(S)$ was evaluated using Cochran's $G$ test. As $G_{\text {exp }}<G_{t_{\text {tab }}}$ all three concentrations studied showed equivalent variance. Therefore, the concentration factor had no influence on the exactness of the methods. The Student $t$ test corroborated exactness, with $t$ values that were lower than tabulated $t$ values, showing no statistically significant differences between average recovery and the 100 $\%$ samples. Consequently, the technique can be confirmed as being exact and was not affected significantly by system errors.

To assess repeatability, coefficient of variation was estimated by analyzing a single concentration of samples in replicate (6 times). Coefficient of variation values were found to be well below the $3 \%$ established limit.

In terms of intermediate precision, results were also satisfactory. A coefficient of variation was obtained which fulfilled the acceptance criteria for a $\mathrm{CV}$ of $\leq 3 \%$. Random errors therefore did not affect the methods to any meaningful degree. This analysis was complemented with Fisher's $\mathrm{F}$ and Student $\mathrm{t}$ tests. In both analyses, $\mathrm{F}_{\text {exp }}<\mathrm{F}_{\text {tab}^{\prime}}$ showing no significant differences in the results obtained by the analysts, regardless of which days the tests were performed on. Values for $t_{\exp }$ were lower than $t_{\text {tab }}$ in every case, showing no significant differences among the average values obtained by the analysts. The consistency found in all of these results confirms the precision of the methods.

Table 2. Summary of the statistical processing of validation results for chitosan acetate

\begin{tabular}{|c|c|c|c|}
\hline Parameter & \multicolumn{2}{|l|}{ Results } & Acceptance criteria \\
\hline Linearity & \multicolumn{2}{|c|}{$\begin{array}{l}\mathrm{Y}=0.03267+0.025 \mathrm{x} \\
r=0.999 \\
r^{2}=0.999 \\
S b_{\text {rel }}=1.28 \% \\
\mathrm{CV}_{\mathrm{f}}=2.05 \%\end{array}$} & $\begin{array}{l}Y=b X+a \\
r \geq 0.999 \\
r^{2} \geq 0.980 \\
S b_{\text {rel }} \leq 2 \% \\
\mathrm{CV}_{\mathrm{f}} \leq 5 \%\end{array}$ \\
\hline Exactness & \multicolumn{2}{|c|}{$\begin{array}{l}\mathrm{R}_{80 \%}=100.05 \% \mathrm{CV}_{80 \%}=0.03 \% \\
\mathrm{R}_{100 \%}=100.19 \% \mathrm{CV}_{100 \%}=0.30 \% \\
\mathrm{R}_{120 \%}=100.02 \% \mathrm{CV}_{120 \%}=0.20 \% \\
\mathrm{R}=100.09 \% \\
\mathrm{CV}=0.17 \% \\
\mathrm{G}_{\mathrm{cal}}=0.653 \\
\mathrm{G}_{\text {tab(3;3 } 30.05)}=0.797 \\
t_{\text {exp }}=1.92 \\
\mathrm{t}_{\text {tab }(10 ; 0,05)}=2.30\end{array}$} & $\begin{array}{l}98.0-102.0 \% \\
C V=2 \% \\
\text { Cochran test } \\
\text { Gcal } \leq G_{\text {tab }} \\
\text { Student } \mathrm{t} \text { test } \\
t_{\text {exp }} \leq t_{\text {tab }}\end{array}$ \\
\hline Repeatability & \multicolumn{2}{|l|}{$\mathrm{CV}=0.78 \%$} & $C V \leq 3 \%$ \\
\hline \multirow[t]{2}{*}{ Intermediate precision } & $\begin{array}{l}\text { Analysts } \\
F_{\text {exp }}=1.06 \\
F_{\text {tab }(10 ; 10 ; 0,05)}=2.97 \\
t_{\text {exp }}=1.24 \\
t_{\text {tab }(22 ; 0,05)}=2.07\end{array}$ & $\begin{array}{l}\text { Days } \\
F_{\text {exp }}=0.78 \\
t_{\text {exp }}=1.01\end{array}$ & \multirow[t]{2}{*}{$\begin{array}{c}F_{\text {exp }} \leq F_{\text {tab }} \\
t_{\text {exp }} \leq t_{\text {tab }} \\
C V_{\text {total }} \leq 2 \%\end{array}$} \\
\hline & \multicolumn{2}{|l|}{$C V_{\text {total }}=0.46 \%$} & \\
\hline
\end{tabular}


Table 3. Summary of the statistical processing of validation results for chitosan lactate

\begin{tabular}{|c|c|c|c|}
\hline Parameter & \multicolumn{2}{|l|}{ Results } & Acceptance criteria \\
\hline Linearity & \multicolumn{2}{|c|}{$\begin{array}{l}\mathrm{Y}=0.03267+0.025 \mathrm{x} \\
r=0.999 \\
r^{2}=0.999 \\
S b_{\text {rel }}=1.28 \% \\
\mathrm{CV}_{\mathrm{f}}=2.05 \%\end{array}$} & $\begin{array}{l}Y=b X+a \\
r \geq 0.999 \\
r^{2} \geq 0.980 \\
S b_{\text {rel }} \leq 2 \% \\
\mathrm{CV}_{\mathrm{f}} \leq 5 \%\end{array}$ \\
\hline Exactness & \multicolumn{2}{|c|}{$\begin{array}{l}\mathrm{R}_{80 \%}=99.98 \% \mathrm{CV}_{80 \%}=0.05 \% \\
\mathrm{R}_{100 \%}=99.91 \% \mathrm{CV}_{100 \%}=0.04 \% \\
\mathrm{R}_{120 \%}=100.01 \% \mathrm{CV}_{120 \%}=0.07 \% \\
\mathrm{R}=99.96 \% \\
\mathrm{CV}=0.06 \% \\
\mathrm{G}_{\text {cal }}=0.643 \\
\mathrm{G}_{\operatorname{tab}(3 ; 3 ; 0,05)}=0.797 \\
t_{\exp }=1.71 \\
\mathrm{t}_{\operatorname{tab}(10 ; 0,05)}=2.30\end{array}$} & $\begin{array}{l}98.0-102.0 \% \\
C V=2 \% \\
\text { Cochran test } \\
\text { Gcal } \leq \mathrm{G}_{\mathrm{tab}} \\
\text { Student } \mathrm{t} \text { test } \\
\mathrm{t}_{\text {exp }} \leq \mathrm{t}_{\mathrm{tab}}\end{array}$ \\
\hline Repeatability & \multicolumn{2}{|l|}{$C V=0.23 \%$} & $C V \leq 3 \%$ \\
\hline \multirow[t]{2}{*}{ Intermediate precision } & $\begin{array}{l}\text { Analysts } \\
F_{\text {exp }}=0.37 \\
F_{\text {tab }(10 ; 10 ; 0,05)}=2.97 \\
t_{\exp }=0.29 \\
t_{\text {tab }(22 ; 0,05)}=2.07\end{array}$ & $\begin{array}{l}\text { Days } \\
F_{\text {exp }}=0.42 \\
t_{\text {exp }}=0.36\end{array}$ & \multirow[t]{2}{*}{$\begin{array}{l}F_{\text {exp }} \leq F_{\text {tab }} \\
t_{\text {exp }} \leq t_{\text {tab }} \\
C V_{\text {total }} \leq 2 \%\end{array}$} \\
\hline & \multicolumn{2}{|l|}{$C V_{\text {total }}=0.24 \%$} & \\
\hline
\end{tabular}

Table 4. Stability ${ }^{\mathrm{a}}$ of spray-dried chitosan acetate

\begin{tabular}{|c|c|c|c|c|c|c|}
\hline \multicolumn{2}{|l|}{ Parameter } & \multicolumn{5}{|c|}{ Time (months) } \\
\hline & & Initial & 3 & 6 & 9 & 12 \\
\hline $\begin{array}{l}\text { Organoleptic charac- } \\
\text { teristics }\end{array}$ & $\begin{array}{l}\mathrm{B}^{\star} 1 \\
\mathrm{~B} 2 \\
\mathrm{~B} 3\end{array}$ & $\begin{array}{l}\text { Accepted } \\
\text { Accepted } \\
\text { Accepted }\end{array}$ & $\begin{array}{l}\text { Accepted } \\
\text { Accepted } \\
\text { Accepted }\end{array}$ & $\begin{array}{l}\text { Accepted } \\
\text { Accepted } \\
\text { Accepted }\end{array}$ & $\begin{array}{l}\text { Accepted } \\
\text { Accepted } \\
\text { Accepted }\end{array}$ & $\begin{array}{l}\text { Accepted } \\
\text { Accepted } \\
\text { Accepted }\end{array}$ \\
\hline $\mathrm{pH}(\mathrm{n}=3)$ & $\begin{array}{l}\text { B1 } \\
\text { B2 } \\
\text { B3 }\end{array}$ & $\begin{array}{l}5.97(0.001) \\
5.70(0.001) \\
6.27(0.002)\end{array}$ & $\begin{array}{l}5.97(0.015) \\
5.67(0.002) \\
6.11(0.001)\end{array}$ & $\begin{array}{l}5.98(0.002) \\
5.74(0.005) \\
6.28(0.001)\end{array}$ & $\begin{array}{l}5.22(0.001) \\
5.71(0.007) \\
6.08(0.002)\end{array}$ & $\begin{array}{l}5.47(0.002) \\
5.82(0.005) \\
6.12(0.007)\end{array}$ \\
\hline Loss on drying $(\mathrm{n}=3)$ & $\begin{array}{l}\text { B1 } \\
\text { B2 } \\
\text { B3 }\end{array}$ & $\begin{array}{l}4.80(0.005) \\
4.80(0.005) \\
4.50(0.001)\end{array}$ & $\begin{array}{l}4.85(0.002) \\
4.82(0.002) \\
4.62(0.007)\end{array}$ & $\begin{array}{l}5.00(0.015) \\
4.89(0.002) \\
4.72(0.001)\end{array}$ & $\begin{array}{l}5.22(0.002) \\
5.17(0.001) \\
4.88(0.007)\end{array}$ & $\begin{array}{l}5.26(0.001) \\
5.29(0.002) \\
4.97(0.001)\end{array}$ \\
\hline $\mathrm{DD}($ molar $)(\%)(\mathrm{n}=3)$ & $\begin{array}{l}\text { B1 } \\
\text { B2 } \\
\text { B3 }\end{array}$ & $\begin{array}{l}57.36(0.01) \\
56.70(0.02) \\
48.86(0.01)\end{array}$ & $\begin{array}{l}57.25(0.15) \\
56.66(0.04) \\
48.79(0.06)\end{array}$ & $\begin{array}{l}57.15(0.05) \\
56.51(0.06) \\
48.61(0.06)\end{array}$ & $\begin{array}{l}57.12(0.08) \\
56.43(0.05) \\
48.50(0.05)\end{array}$ & $\begin{array}{l}57.10(0.05) \\
56.37(0.05) \\
48.42(0.03)\end{array}$ \\
\hline $\begin{array}{l}\text { Microbiologic analyses } \\
\text { (UFC/g) }\end{array}$ & $\begin{array}{l}\text { B1 } \\
\text { B2 } \\
\text { B3 }\end{array}$ & $\begin{array}{l}\text { TA: } 40 \\
\text { TC: }<10 \\
\text { TA: } 42 \\
\text { TC: }<10 \\
\text { TA: } 40 \\
\text { TC: }<10\end{array}$ & & & & $\begin{array}{l}\text { TA: } 38 \\
\text { TC: }<10 \\
\text { TA: } 41 \\
\text { TC: }<10 \\
\text { TA: } 40 \\
\text { TC: }<10\end{array}$ \\
\hline
\end{tabular}

${ }^{a}$ Mean (standard deviation)

$\mathrm{B}^{*}$ : batch, TA: Total aerobic microbial count, TC: Total combined yeast/mold count 
Table 5. Stability of spray-dried chitosan lactate

\begin{tabular}{|c|c|c|c|c|c|c|}
\hline \multicolumn{2}{|l|}{ Parameter } & \multicolumn{5}{|c|}{ Time (months) } \\
\hline & & Initial & 3 & 6 & 9 & 12 \\
\hline $\begin{array}{l}\text { Organoleptic charac- } \\
\text { teristics }\end{array}$ & $\begin{array}{l}\mathrm{B}^{*} 1 \\
\mathrm{~B} 2 \\
\mathrm{~B} 3\end{array}$ & $\begin{array}{l}\text { Accepted } \\
\text { Accepted } \\
\text { Accepted }\end{array}$ & $\begin{array}{l}\text { Accepted } \\
\text { Accepted } \\
\text { Accepted }\end{array}$ & $\begin{array}{l}\text { Accepted } \\
\text { Accepted } \\
\text { Accepted }\end{array}$ & $\begin{array}{l}\text { Accepted } \\
\text { Accepted } \\
\text { Accepted }\end{array}$ & $\begin{array}{l}\text { Accepted } \\
\text { Accepted } \\
\text { Accepted }\end{array}$ \\
\hline $\mathrm{pH}(\mathrm{n}=3)$ & $\begin{array}{l}\text { B1 } \\
\text { B2 } \\
\text { B3 }\end{array}$ & $\begin{array}{l}4.10(0.002) \\
4.30(0.002) \\
4.10(0.015)\end{array}$ & $\begin{array}{l}4.29(0.001) \\
4.35(0.002) \\
4.11(0.002)\end{array}$ & $\begin{array}{l}4.17(0.018) \\
4.27(0.002) \\
4.10(0.015)\end{array}$ & $\begin{array}{l}4.38(0.012) \\
4.39(0.012) \\
4.10(0.015)\end{array}$ & $\begin{array}{l}4.16(0.012) \\
4.82(0.002) \\
4.18(0.001)\end{array}$ \\
\hline Loss on drying $(\mathrm{n}=3)$ & $\begin{array}{l}\text { B1 } \\
\text { B2 } \\
\text { B3 }\end{array}$ & $\begin{array}{l}3.20(0.015) \\
2.60(0.002) \\
2.50(0.002)\end{array}$ & $\begin{array}{l}3.25(0.002) \\
2.62(0.001) \\
2.59(0.001)\end{array}$ & $\begin{array}{l}3.37(0.015) \\
2.67(0.002) \\
2.61(0.009)\end{array}$ & $\begin{array}{l}3.46(0.002) \\
2.69(0.013) \\
2.68(0.001)\end{array}$ & $\begin{array}{l}3.52(0.0015) \\
2.71(0.002) \\
2.72(0.002)\end{array}$ \\
\hline $\begin{array}{l}\text { DD (molar) }(\%) \\
(\mathrm{n}=3)\end{array}$ & $\begin{array}{l}\text { B1 } \\
\text { B2 } \\
\text { B3 }\end{array}$ & $\begin{array}{l}53.83(0.01) \\
53.60(0.01) \\
53.10(0.05)\end{array}$ & $\begin{array}{l}53.80(0.01) \\
53.52(0.03) \\
53.08(0.01)\end{array}$ & $\begin{array}{l}53.75(0.05) \\
53.57(0.05) \\
52.89(0.01)\end{array}$ & $\begin{array}{l}53.71(0.02) \\
53.49(0.02) \\
52.76(0.05)\end{array}$ & $\begin{array}{l}53.62(0.05) \\
53.38(0.02) \\
52.67(0.03)\end{array}$ \\
\hline $\begin{array}{l}\text { Microbiologicanalyses } \\
\text { (UFC/g) }\end{array}$ & $\begin{array}{l}\text { B1 } \\
\text { B2 } \\
\text { B3 }\end{array}$ & $\begin{array}{l}\text { TA: } 23 \\
\text { TC: }<10 \\
\text { TA: } 20 \\
\text { TC: }<10 \\
\text { TA: } 25 \\
\text { TC: }<10\end{array}$ & & & & $\begin{array}{l}\text { TA: } 20 \\
\text { TC: }<10 \\
\text { TA: } 22 \\
\text { TC: }<10 \\
\text { TA: } 23 \\
\text { TC: }<10\end{array}$ \\
\hline
\end{tabular}

${ }^{a}$ Mean (standard deviation)

$\mathrm{B}^{*}$ : batch, TA: Total aerobic microbial count, TC: Total combined yeast/mold count

Both methods complied with international standards for the validation of analytical techniques, and therefore guarantee that those procedures are linear, precise and exact for the estimation of this important parameter in the physicalchemical characterization of chitosan salts, within the concentration range studied. The proposed methods for the determination of degree of (molar) deacetylation of chitosan acetate and chitosan lactate samples were successfully validated. Such methods could be used for the purposes of quality control and stability study of chitosan salts.

Throughout the study, salts remained in powder form, with a light-yellow to dark-yellow coloration. Values of loss on drying (2.5 - 5.2\%) of chitosan salts using acetic or lactic acid, as a solvents, indicated the good quality of spraydried particles of chitosan. Higher loss on drying values were obtained with chitosan acetate compared to the respective values with chitosan lactate, but in both cases they were below $10 \%{ }^{34,35}$. The present results were consistent with previous findings ${ }^{22}$. Similar behavior was obtained regarding $\mathrm{pH}$. The utility of the spectrophotometric method was verified by means of replicate estimations of the degree of (molar) deacetylation for a 12-month period.

Spray-dried chitosan particles, stored in double polyethylene bags and multilayer paper bags, were of good quality $^{34,35}$. The suggested method was successfully applied to the determination of the degree of (molar) deacetylation of spray-dried chitosan acetate and chitosan lactate samples during the stability study. Chitosan salts stored in double polyethylene bags and multilayer paper bags showed an adequate stability during a 12-month period.

\section{CONCLUSION}

The proposed methods for the determination of the degree of (molar) deacetylation of chitosan acetate and chitosan lactate salts did not interfere in the analysis, which proved their specificity. UV methods were found to be simple, rapid, precise and accurate. The statistical data proved that the two methods complied with international standards for the validation of analytical techniques. The methods can be used for routine quality control and stability of spray-dried chitosan acetate and chitosan lactate salts, as raw materials. Spray-dried chitosan salts stored in double polyethylene bags and multilayer paper bags showed an adequate stability during a 12-month period.

\section{REFERENCES}

1. Shahidi F, Arachchi JKV, Jeon Y. Food applications of chitin and chitosans. Trends Food Sci. Technol 1999; 10: 37-51.

2. Rege PR, Garmise RJ, Block LH. Spray-dried chitinosans. Part I: preparation and characterization. Int. J. Pharm 2003; 252; 41-51.

3. Muzzarelli RAA, Baldassare V, Conti F, Ferrara P, Biagini G, Gazzanelli G, Vasi V. Biological activity of chitosan: ultrastructure study. Biomaterials 1988; 9: 247-252. 
4. Koide SS. Chitin-chitosan: properties, benefits and risks. Nutr. Res 1998; 18: 1091-1101.

5. Kumar MNVR. A review of chitin and chitosan applications. React. Funct. Polym 2000; 46: 1-27.

6. Illum L. Chitosan and its use as a pharmaceutical excipient. Pharm. Res 1998; 15; 1326-1331.

7. Dutta PK, Ravikumar MNV, Dutta J. Chitin and chitosan for versatile applications. Polym. Rev 2002; 42(3): 307-354.

8. Sinha VR, Singla AK, Wadhawan S, Kaushik R, Kumria R, Bansal K, Dhawan S. Chitosan microspheres as a potential carrier for drugs. Int. J. Pharm 2004; 274: 1-33.

9. Paños I, Acosta N, Heras A. New Drug Delivery Systems Based on Chitosan. Curr. Drug Discov. Technol 2008; 5: 333341.

10. Patel MP, Patel RR, Patel JK. Chitosan mediated targeted drug delivery system: a review. J. Pharm. Pharmaceut. Sci 2010; 13(3): 536 - 557.

11. Bharti AD, Keservani RK, , Sharma AK, Kesharwani RK, Husain GM. Formulation and In Vitro Characterization of Metoprolol Tartrate Loaded Chitosan Microspheres. Ars Pharm 2012; 53(3): 13-18.

12. Sharma AK, Keservani RK, Dadarwal SC, Choudhary YL, Ramteke S. Formulation and In Vitro Characterization of Cefpodoxime Proxetil Gastroretentive Microballoons. DARU J Pharm Sci 2011; 19(1): 33-40.

13. European Pharmacopoeia. Council of Europe Strasbourg. $4^{\text {th }}$ Edition, 2002, p. 875-876.

14. Kosaraju SL, D'ath L, Lawrence A. Preparation and characterization of chitosan microspheres for antioxidant delivery. Carbohydr. Polym 2006; 64: 163-167.

15. Gharsallaoui A, Roudaut G, Chambin O, Voilley A, Saurel R. Applications of spray-drying in microencapsulation of food ingredients: an overview. Food Res. Int 2007; 40(9): 1107-1121.

16. Aranaz I, Mengíbar M, Harris R, Paños I, Miralles B, Acosta $\mathrm{N}$, et al.. Functional characterization of chitin and chitosan. Curr. Chem. Biol 2009; 3: 203-230.

17. Yurdasiper A, Sevgi F. An overview of modified release chitosan, alginate and eudragit RS microparticles. J. Chem. Pharm. Res 2010; 2(3): 704-721.

18. Nogueiro B, Rocha F, Santos L, Alves A. Microencapsulation with chitosan by spray drying for industry applications. A review. Trends Food Sci. Technol 2013; 31: 138-155.

19. Hidalgo C, Fernández M, Nieto OM, Paneque AA, Fernández G, Llópiz, JC. Estudio de quitosanos cubanos derivados de la quitina de la langosta. Rev. Iberoam. Polím 2009; 10: 1-17.

20. de la Paz N, Fernández M, López OD, Nogueira A, García $\mathrm{CM}$, Pérez D, et al.. Optimización del proceso de obtención de quitosana derivada de quitina de langosta. Rev. Iberoam. Polím 2012; 13(3): 103-116.

21. de la Paz N, Pérez D, Fernández M, García C, López OD, Nogueira A. Estabilidad de la quitosana derivada de quitina de langosta Panulirus argus, materia prima. Ars Pharm 2013; 54(4): 16-23.

22. Cervera MF, Heinämäki J, de la Paz N, López O, Maunu SL, Virtanen $\mathrm{T}$, et al.. Effects of spray drying on physicochemical properties of chitosan acid salts. AAPS Pharm Sci Tech 2011; 12(2): 637-49.

23. Khan TA. Reporting degree of deacetylation values of chitosan: the influence of analytical methods. J. Pharm. Pharmaceutic. Sci 2002; 5(3): 205-212.

24. Xuan J, Lirong Ch, Wei Z. A new linear potentiometric titration method for the determination of deacetylation degree of chitosan. Carbohydr. Polym 2003; 54: 457-463.

25. Hidalgo C, Suárez Y, Fernández M. Validación de una técnica potenciométrica para determinar el grado de desacetilación de la quitosana. Ars Pharm 2008; 49: 245-257.

26. Muzarelli RAA, Rochetti R. Determination of the degree of acetylation of chitosans by first derivative ultraviolet spectrophotometry. Carbohydr Polym 1985; 5: 461-472.

27. Fernández M, Heinämäki J, Räsänen M, Maunu S.L, Karjalainen M, Nieto OM, et al.. Solid-state characterization of chitosans derived from lobster chitin. Carbohydr Polym 2004; 58: $401-408$

28. Hirai A, Odani H, Nakajima A. Determination of degree of deacetylation of chitosan by ${ }^{1} \mathrm{H}$ NMR spectroscopy. Polym. Bull 1991; 26: 87-94.

29. Raymond L, Morin FG, Marchessault RH. Degree of deacetylation of chitosan using conductometric titration and solidstate NMR. Carbohydr. Res 1993; 246: 331-336.

30. Heux L, Brugnerotto J, Desbrieres J, Versali MF, Rinaudo M. Solid state NMR for determination of degree of acetylation of chitin and chitosan. Biomacromolecules 2000; 1: 746-751.

31. Kasaai MR. Determination of the degree of $\mathrm{N}$-acetylation for chitin and chitosan by various NMR spectroscopy techniques: A review. Carbohydr. Polym 2010; 79: 801-810.

32. United State Pharmacopeia (USP 35). United States Pharmacopoeia (USP 35/2012 NF 30). US Pharmacopoeia Convention, 2012, p. 967 - 971.

33. Regulación No. 47 CECMED. Validación de Métodos Analíticos. MINSAP. Cuba. 2013, p. 3-25.

34. European Pharmacopoeia. Council of Europe Strasbourg. Sixt Edition. 2008, Volume 2, p.1490.

35. Rowe RC, Sheskey PJ, Quinn ME. Chitosan. In: Handbook of Pharmaceutical Excipients. Six Edition. Pharmaceutical Press, Italy, 2009. Electronic version. 